\title{
Expression of Nerve Growth Factor and Tyrosine Kinase A in Laryngeal Squamous Cell Carcinoma: A Novel Study
}

\author{
MOSTAFA A. ABOU SARIE, M.D.*; HALA M. EL-HANBULI, M.D.* and LUBNA O. ABDEL-SALAM, M.D.** \\ The Department of Pathology, Faculty of Medicine, Fayoum* and Cairo** Universities, Egypt
}

\begin{abstract}
Background: Laryngeal Squamous Cell Carcinoma (LS$\mathrm{CC}$ ) is a common cancer worldwide so knowing the biological markers related to this tumor aggressiveness can help improving the patient's management. A recent attention was payed towards Nerve Growth Factor (NGF) and its receptors in tumorigenesis.
\end{abstract}

Aim of Study: This work aimed at studying for the first time the immunohistochemical expression of NGF and its TrkA receptor in LSCC and determine the possibility of finding a relationship between their expression and the different clinicopathological data of the patients especially the clinical stage of the disease.

Material and Methods: Using the immunohistochemical staining, the expression of NGF and TrkA was evaluated in 60 LSCC tissues.

Results: The result showed that the expression of both NGF and TrkA was significantly related to the nodal status, the tumor and the clinical stages of the patients $(p<0.001)$.

Conclusion: The increased expression of both markers in advanced clinical stage of the disease suggested considering them as potential markers not only as prognostic factors, but also as a therapeutic target in LSCC.

Key Words: Laryngeal Squamous Cell Carcinoma (LSCC)Nerve Growth Factor (NGF) - Tropomyosinrelated kinase A (TrkA).

\section{Introduction}

CANCER of the larynx is one of the most common types of head and neck cancer. Laryngeal cancer is also the second most common tumor of the respiratory tract and is the eleventh most common cancer worldwide with high mortality rate. Among them, the Laryngeal Squamous Cell Carcinoma

Correspondence to: Dr. Hala M. El-Hanbuli, E-Mail address: hmh06@fayoum.edu.eg
(LSCC) accounts for approximately 95\% of all malignant tumors of the larynx [1].

Several risk factors have been implicated in the pathogenesis of laryngeal cancer, including tobacco use, alcohol consumption, air pollution, genetics, nutrition, bacterial infection, life-style and occupational factors [2] .

The prognosis of LSCCs is known to be affected by the clinical stage [3], site and size of the tumor, histological grading and depth of invasion [4] However, the invasion and metastasis of LSCC are the main factors that severely affect patients' life quality and overall survival [5]. Although great progress has been achieved in the studies on LSCC, there are no ideal markers for the decision of prognosis and the guidance of treatment in these patients.

Nerve Growth Factor (NGF) is a growth factor that belongs to the neurotrophin family [6]. It is essential to the development of the nervous system as it stimulates the outgrowth of sympathetic and sensory neurons [7]. NGF has two structurally different receptors, the $\mathrm{p} 75$ neurotrophin receptor and the Tropomyosin-related kinase A (TrkA). Interaction of NGF with its receptors regulates the NGF functions as a signaling molecule, whereas the specific tyrosine kinase receptors TrkA binds the NGF [8].

Recent studies have shown the presence of NGF and its receptors in variety of human tissues other than in the nervous system alone, and their overexpression may promote the proliferation, growth and invasion in several types of cancer, such as neuroblastoma, breast carcinoma, colon cancer and oral carcinoma [9]. Trk receptors have also been shown to act as oncogenes with roles in 
malignant transformation, metastasis, and survival signaling in human tumors [10].

\section{Material and Methods}

\section{Tissue sample:}

A total of 60 formalin-fixed, paraffin-embedded LSCC tissues were obtained between 2015 and 2018 from Pathology Department, Faculty of Medicine, Cairo University (Egypt). Exclusion criteria were pre-operative chemo-or radio-therapy prior to surgery. All clinical data, such as, gender, age, tumor site and size, histologic grade, perineural and lympho-vascular invasion. TNM and clinical staging were done according to American Joint Committee on Cancer (AJCC) Cancer Staging Manual, 8 th edition.

\section{Immunohistochemical staining:}

Formalin-fixed paraffin embedded three sections from each tumor tissue block were cut at 35-micron thickness. One section was mounted on a glass slide then stained with routine Hematoxylin and Eosin stain ( $\mathrm{H} \& \mathrm{E}$ ) for histopathological evaluation. The other two sections were mounted on positive charged sides to be immunostained with antiNGF antibody and antiTrkA antibody. After inactivation of endogenous peroxidases with $0.3 \% \mathrm{H}_{2} \mathrm{O}_{2}$, and blocking with $2.5 \%$ horse serum, primary followed by subjection of the sections for secondary antibodies, and revealed with DAB Peroxidase (HRP) Substrate Kit (Vector Laboratories, California, USA, catalogue number SK-4100). The following primary antibodies were used at 1/500 dilution, anti-NGF (ab52918, Abcam) and anti-TrkA (2508, Cell Signaling), finally, slides were counterstained with hematoxylin dehydrated and cleared in xylene before mounting.

\section{Immunohistochemical assessment:}

Nerve Growth Factor (NGF) was expressed diffusely in the cytoplasm and TrkA was expressed in the cytoplasm and the membrane of LSCC tissues however membranous staining only was considered positive. A scoring system was used to classify the immunoreactivity, which was graded as follows: $0=$ negative, $1=$ up to $10 \%$ positive cells, $2=11-50 \%$ positive cells, $3=51-80 \%$ positive cells, and $4=$ more than $80 \%$ positive cells. Sample scores of 3 and 4 were defined as having high immunoreactivity [11], and samples scores of 0-2 were defined as having no/low immunoreactivity, combined for statistical purposes. The slides were examined by two independent pathologists and revised by the third for more accuracy.

\section{Statistical analysis:}

The collected data was organized, tabulated and statistically analyzed using SPSS software statistical computer package version 18 (SPSS Inc, USA). For quantitative data, the mean, Standard Deviation (SD) will be calculated. For qualitative data the number and percent distribution will be calculated, chi square $(\chi)$ or fisher exact test where appropriate will be used as a test of significance. For interpretation of results of tests of significance, significance will be adopted at $p<0.05$.

\section{Results}

Expression of NGF and TrkA in LSCC tissues: (Table 1):

Among 60 LSCC specimens, 30 (50\%) specimens showed high cytoplasmic immunoreactivity for NGF Fig. (1A) while the other half of the specimens $30(50 \%)$ showed no/low cytoplasmic immunoreactivity Fig. (1B). The membranous expression of TrkA was high in $25(41.7 \%)$ Fig. (2A) and no/low expression in $35(58.3 \%)$ of the total examined specimens.

Relation between the expression of NGF and TrkA and clinicopathological characteristics of LSCC patients: (Table 2):

There was no significant association between NGF or TrkA expression and other examined factors except for the nodal status, tumor and clinical stage $(p<0.001)$. 6.7.

The mean age for the studied cases was $63.6 \pm$

Correlation between the expression of NGF and TrkA in LSCC:

A significant relation between NGF and TrkA immunohistochemical expression was found ( $p$ $<0.001)$, and their intensity of staining was positively correlated to each other $(r=0.933) \mathrm{Fig}$. (3).

Table (1): Expression of NGF and TrkA in LSCC.

\begin{tabular}{|c|c|c|c|c|c|c|}
\hline \multirow{3}{*}{ Variable } & \multicolumn{3}{|c|}{$\begin{array}{c}\text { No/low } \\
\text { immunoreactivity }\end{array}$} & \multicolumn{2}{|c|}{$\begin{array}{c}\text { High } \\
\text { immunoreactivity }\end{array}$} & \multirow{3}{*}{ Tota } \\
\hline & 0 & 1 & 2 & 3 & 4 & \\
\hline & \multicolumn{5}{|c|}{ Number (\%) } & \\
\hline \multirow[t]{2}{*}{ NGF } & $15(25)$ & $9(15)$ & $6 \quad(10)$ & $14(23.3)$ & $16(26.7)$ & 60 \\
\hline & \multicolumn{3}{|c|}{$30(50)$} & \multicolumn{2}{|c|}{$30(50)$} & \\
\hline \multirow[t]{2}{*}{ TrkA } & $15(25)$ & $9(15)$ & $11(18)$ & $16(26.7)$ & $9 \quad(15)$ & \\
\hline & \multicolumn{3}{|c|}{$35(58.3)$} & \multicolumn{2}{|c|}{$25(41.7)$} & \\
\hline
\end{tabular}


Table (2): Immunohistochemical expression of NGF and TrkA in tissues of $60 \mathrm{LSCC}$ patients and their relation to the clinicopathological factors.

\begin{tabular}{|c|c|c|c|c|c|c|c|}
\hline \multirow[t]{2}{*}{ Variables } & \multirow[t]{2}{*}{$\mathrm{N}(\%)$} & \multicolumn{2}{|c|}{$\begin{array}{c}\text { NGF } \\
\text { immunore- } \\
\text { activity }\end{array}$} & \multirow[t]{2}{*}{$p$} & \multicolumn{2}{|c|}{$\begin{array}{c}\text { TrkA } \\
\text { immunore- } \\
\text { activity }\end{array}$} & \multirow[t]{2}{*}{$p$} \\
\hline & & $\begin{array}{l}\mathrm{No} / \\
\text { low }\end{array}$ & High & & $\begin{array}{l}\mathrm{No} / \\
\text { low }\end{array}$ & High & \\
\hline Gender: & & & & 1 & & & 0.484 \\
\hline - Male & $56(93.3)$ & 28 & 28 & & 32 & 24 & \\
\hline - Female & $4 \quad(6.7)$ & 2 & 2 & & 3 & 1 & \\
\hline Age (years): & & & & 1 & & & 0.195 \\
\hline$\cdot 560$ & $20(33.3)$ & 10 & 10 & & 14 & 6 & \\
\hline$\cdot>60$ & 40 (66.7) & 20 & 20 & & 21 & 19 & \\
\hline Tumor & & & & & & & \\
\hline localization: & & & & 0.602 & & & 0.93 \\
\hline - Glottis & 34 (56.7) & 18 & 16 & & 20 & 14 & \\
\hline $\begin{array}{l}\text { - Subglottis, } \\
\text { Supraglottis, } \\
\text { Transglottis }\end{array}$ & $26(43.3)$ & 12 & 14 & & 15 & 11 & \\
\hline $\begin{array}{l}\text { Histological } \\
\text { grading: }\end{array}$ & & & & 0.432 & & & 0.279 \\
\hline - 1 & 7 (11.7) & 5 & 2 & & 6 & 1 & \\
\hline$\cdot 2$ & $30(50)$ & 15 & 15 & & 17 & 13 & \\
\hline$\cdot 3$ & $23(38.3)$ & 10 & 13 & & 12 & 11 & \\
\hline Lymphovascu- & & & & & & & \\
\hline lar invasion: & & & & 0.117 & & & 0.368 \\
\hline - Positive & $47(78.3)$ & 21 & 26 & & 26 & 21 & \\
\hline - Negative & $13(21.7)$ & 9 & 4 & & 9 & 4 & \\
\hline $\begin{array}{l}\text { Perineural } \\
\text { invasion: }\end{array}$ & & & & 0.118 & & & 0.538 \\
\hline - Positive & $26(43.3)$ & 10 & 16 & & 14 & 12 & \\
\hline - Negative & $34(56.7)$ & 20 & 14 & & 21 & 13 & \\
\hline T stage: & & & & $<0.001 *$ & & & $<0.001 *$ \\
\hline$\cdot 1$ & $16(26.7)$ & 14 & 2 & & 15 & 1 & \\
\hline$\cdot 2$ & $16(26.7)$ & 11 & 5 & & 13 & 3 & \\
\hline$\cdot 3$ & $17(28.3)$ & 5 & 12 & & 7 & 10 & \\
\hline$\bullet 4$ & $11(18.3)$ & 0 & 11 & & 0 & 11 & \\
\hline N status: & & & & $<0.001$ & & & $<0.001$ \\
\hline - Negative & $24(40)$ & 21 & 3 & & 21 & 3 & \\
\hline - Positive & $36(60)$ & 9 & 27 & & 14 & 22 & \\
\hline Clinical stage: & & & & $<0.001 *$ & & & $<0.001 *$ \\
\hline - I & $12(20)$ & 12 & 0 & & 12 & 0 & \\
\hline$\cdot$ II & $9 \quad(15)$ & 9 & 0 & & 9 & 0 & \\
\hline • III & $13(21.7)$ & 7 & 6 & & 9 & 4 & \\
\hline$\cdot$ IV & $26(43.3)$ & 2 & 24 & & 5 & 21 & \\
\hline
\end{tabular}

*: Difference in tumor stage: T1 \& T2 versus T3 \& T4 and in clinical stage: I \& II versus III \& IV.

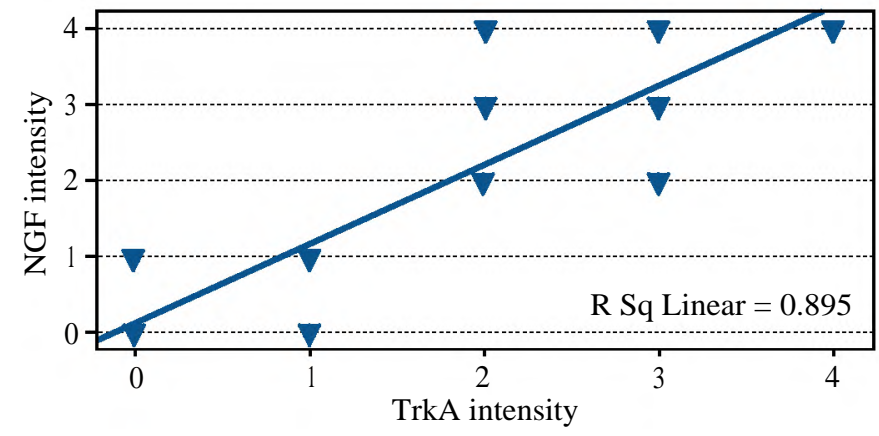

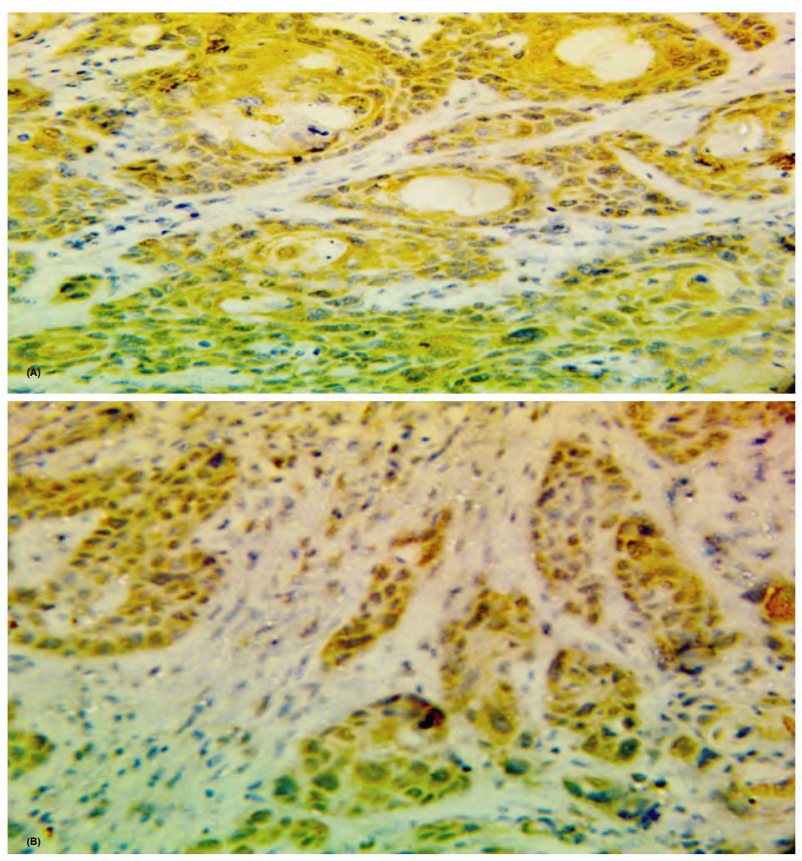

Fig. (1): A- High NGF immunohistochemical cytoplasmic expression in LSCC (X400). B- Low NGF immunohistochemical cytoplasmic expression in LSCC (X400).

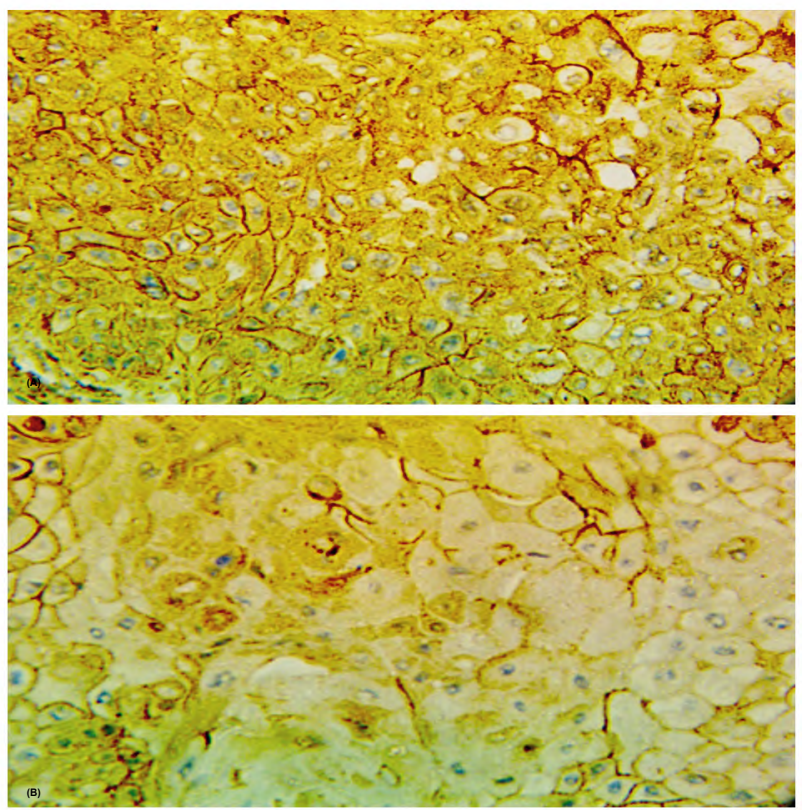

Fig. (2): A- High TrkA immunohistochemical membranous expression in LSCC (X400). B- Low TrkA immunohistochemical membranous expression in LSCC (X400).

Fig. (3): Positive correlation between NGF and TrkA staining intensity in LSCC tissues. 


\section{Discussion}

Laryngeal squamous cell carcinoma is a highly aggressive malignant tumor with increasing incidence and poor prognosis. The prognosis of patients with LSCC after curative treatment remains unsatisfactory [12]. Patients often experience disease relapse due to eventual tumor metastasis and emergence of resistance to therapy [13].

Thus, there is an urgent need to explore relevant factors related to tumorigenesis in order to identify new target molecules for improving treatment and overcoming therapy resistance of laryngeal cancer. In addition, biological markers capable of distinguishing patients with a good prognosis from those with a worse prognosis are thus required.

Emerging evidence indicate the importance of the stimulatory role of nerves in tumor progression [14]. The nerve-cancer cell crosstalk occurs via the liberation of neurotransmitters to stimulate cancer cell growth and dissemination, while neurotrophic factors are released by cancer cells to attract nerve outgrowth in the tumor microenvironment [15].

NGF and its TrkA receptor form a recently recognized important autocrine epithelial survival axis in Head and Neck Squamous Cell Carcinoma (HNSCC), which might be active in cell survival mechanisms following chemotherapeutic treatments. The suggestion of NGF and TrkA1 autocrine loop in HNSCC is absolutely novel [16]. So, the aim of this study was to evaluate the expression of NGF and its receptor TrkA using the immunohistochemistry in LSCC.

The results showed that there was high immunoreactivity for NGF and TrkA in 50\% and $41.7 \%$ of the studied cases respectively, and the expression of both was highly related to tumor stage, nodal status and the clinical stage $(p<0.001)$ and their high immunoreactivity was associated with advanced stages.

A similar increased expression of NGF and its receptor TrkA was previously detected in breast carcinoma [17], thyroid cancer [18], non-small cell lung carcinoma [19] and in squamous cell carcinoma of the lung (Gao et al., 2018) [20]. In addition, NGF immunoreactivity was found to be associated with nodal metastasis in oral cancer [21] suggesting that the upregulation these proteins is a common feature in these cancers.

Neurotrophins may serve as molecular factors involved in the communication between tumor and neuronal cells. They support survival, anti-apoptosis and cell-detachment inducing migratory effects [22]. Therefore, neurotrophins and their receptors might regulate cell survival in HNSCC [16]

Pharmacological inhibitors against TrkA [23] and humanized anti-NGF antibodies [24] have been developed and could therefore be used as therapeutic tools in breast, thyroid and lung cancers.

The knowledge on neurotrophins and neurotrophin receptors in LSCC is particularly important for improving the treatment plan as it provides a supplementary data about the biologic behavior of this tumor.

\section{Conclusion:}

As indicated by the study of the immunohistochemical expression of NGF and TrkA, both are suggested as potential markers not only as prognostic factors, but also as a therapeutic target in LSCC.

\section{References}

1- CHEN P., YU W., HUANG J., XU H., LI G., CHEN X and HUANG Z.: Matched-pair analysis of survival in patients with poorly differentiated versus welldifferentiated glottic squamous cell carcinoma. Oncotarget., 8: 14770-6, 2017.

2- CHATENOUD L., GARAVELLO W., PAGAN E., BERTUCCIO P., GALLUS S.., La VECCHIA C., NEGRI E. and BOSETTI C.: Laryngeal cancer mortality trends in European countries. Int. J. Cancer, 138: 833-42, 2016.

3- PRADIER R., GONZALEZ A., MATOS E., LORIA D., ADAN R., SACO P. and CALIFANO L.: Prognostic factors in laryngeal carcinoma: Experience in 296 male patients. Cancer, 71: 2472-6, 1993.

4- PERA E., MORENO A. and GALINDO L.: Prognostic factors in laryngeal carcinoma: A multifactorial study of 416 cases. Cancer, 58: 928-34 4, 1986.

5- LIU Y., SU Z., LI G., YU C., REN S., HUANG D., FAN S., TIAN Y., ZHANG X. and QIU Y.: Increased expression of metadherin protein predicts worse disease-free and overall survival in laryngeal squamous cell carcinoma. Int. J. Cancer, 133: 671-9, 2013.

6- WANG W., CHEN J. and GUO X.: The role of nerve growth factor and its receptors in tumorigene-sis and cancer pain. Bio Sci Trends, 8: 68-74, 2014.

7- BRADSHAW R.A., et al.: NGF and ProNGF: Regulation of neuronal and neoplastic responses through receptor signaling. Adv. Biol. Regul., 58: 16-27, 2015.

8- SCHECTERSON L.C. and BOTHWELL M.: Neurotrophin re-ceptors: Old friends with new partners. Dev. Neurobiol., 70: 332-8, 2010.

9- YU E.H., LUI M.T., TU H.F., WU C.H., LO W.L., YANG C.C., CHANG K.W. and KAO S.Y.: Oral carcinoma with peri-neural invasion has higher nerve growth factor expression and worse prognosis. Oral Dis., 20: 268-74, 2014. 
10- RUBIN J.B. and SEGAL R.A.: Growth, survival and migration: The Trk to cancer. Cancer Treat. Res., 115: 1$18,2003$.

11- REMMELE W. and SCHICKETANZ K.H.: Immunohistochemical determination of estrogen and progesterone receptor content in human breast cancer. Computer-assisted image analysis (QIC score) vs. subjective grading (IRS). Pathol. Res. Pract., 189: 862-6, 1993.

12- HAMILTON D.W., BINS J.E., McMEEKIN P., PEDERSEN A., STEEN N., De SOYZA A, et al.: Quality compared to quantity of life in laryngeal cancer: A time tradeoff study. Head Neck, 38 (Suppl 1): E631-7, 2016.

13- LIN C.C., FEDEWA S.A., PRICKETT K.K., HIGGINS K.A. and CHEN A.Y.: Comparative effectiveness of surgical and nonsurgical therapy for advanced laryngeal cancer. Cancer, 122 (18): 2845-56, 2016.

14- BOILLY B., FAULKNER S., JOBLING P. and HONDERMARCK H.: Nerve Dependence: From Regeneration to Cancer. Cancer Cell, 31: 342-54, 2017.

15- JOBLING P., et al.: Nerve-Cancer Cell Cross-talk: A Novel Promoter of Tumor Progression. Cancer Res., 75: 1777-81, 2017.

16- DUDÁS J., DIETL W., ROMANI A., REINOLD S., GLUECKERT R., SCHROTT-FISCHER A., DEJACO D., CHACKO L.J., TUERTSCHER R., SCHARTINGER V.H. and RIECHELMANN H.: Nerve Growth Factor (NGF)-Receptor Survival Axis in Head and Neck Squamous Cell Carcinoma Int. J. Mol. Sci., 19: 1771, 2018.

17- LAGADEC C., et al.: TrkA overexpression enhances growth and metastasis of breast cancer cells. Oncogene, 28: 1960-70, 2009.
18- FAULKNER S., et al.: Neurotrophin Receptors TrkA, p75 (NTR), and Sortilin Are Increased and Targetable in Thyroid Cancer. Am. J. Pathol., 188: 229-41, 2018.

19- WANG X.L., YAO Y. and YANG M.: Expression of nerve growth factor and tyrosine kinase $\mathrm{A}$ in non-small cell lung cancer. Int. J. Clin. Exp. Pathol., 9 (2): 2153-8, 2016.

20- GAO F., GRIFFIN N., FAULKNER S., ROWE C.W., WILLIAMS L., ROSELLI S., THORNE R.F., AYSHA FERDOUSHI A., JOBLING P., WALKER M.M. abd HONDERMARCK H.: The neurotrophic tyrosine kinase receptor TrkA and its ligand NGF are increased in squamous cell carcinomas of the lung Scientific Reports, 8: $8135,2018$.

21- YU E.H., LUI M.T., TU H.F., WU C.H., W.L. LO W.L., YANG C.C., K.W. CHANG K.W. and KAO S.Y.: Oral carcinoma with perineural invasion has higher nerve growth factor expression and worse prognosis Oral Diseases, 20: 268-74, 2014.

22- NG Y.K., WONG E.Y., LAU C.P., CHAN J.P., WONG S.C., CHAN A.S., KWAN M.P., TSAO S.W., TSANG C.M., LAI P.B., et al.: K252a induces anoikis-sensitization with suppression of cellular migration in Epstein-Barr virus (EBV)-Associated nasopharyngeal carcinoma cells. Investig. New Drugs, 30: 48-58, 2012.

23-VAISHNAVI A., LE A.T. and DOEBELE R.C.: TRKing down an old oncogene in a new era of targeted therapy. Cancer Discov., 5: 25-34, 2015.

24- CHANG D.S., HSU E., HOTTINGER D.G. and COHEN S.P.: Anti-nerve growth factor in pain management: Current evidence. J. Pain Res., 9: 373-83, 2016.

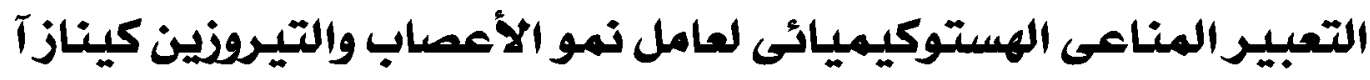

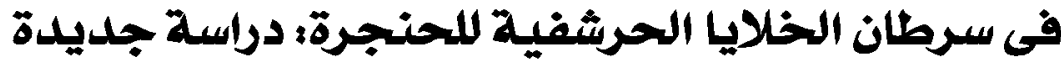

\author{
مقدمة: يعتبر سرطان الخلايا الحرشفية للحنجرة من أكثر السرطانات إنتشاراً عالمياً ولهذا معرفة العلامات البيولوجية لهذا الودم قد يؤلىى

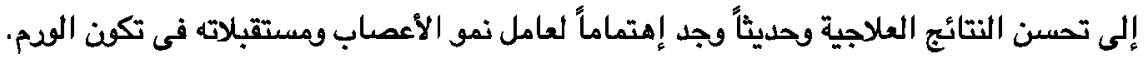

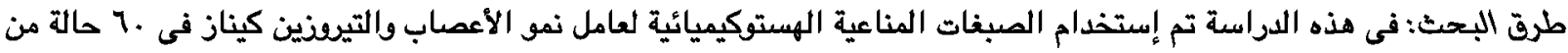

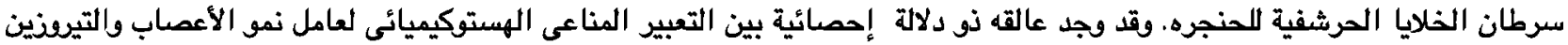 \\ كيناز وإنتشار الودم اللغدد الليمفاويه، درجة الودم والمراحل الإكلينيكية للودم. \\ الخلاصة: خلصت النتائج إلى آن إرتفاع نسبة التعبير المناعى الهستوكيميائى لهذه الدلالات فى المراحل المتقدمه لسرطان الخلايا

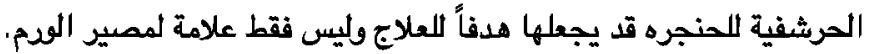

